\title{
PERANCANGAN ALAT BANTU PROSES PEMBUATAN BATIK SARITA
}

\author{
Soleman May Suryanto, Mochammad Chaeron, Tri Wibawa \\ Jurusan Teknik Industri Fakultas Teknik Industri \\ Universitas pembangunan Nasional "Veteran" Yogyakarta \\ Jl. Babarsari 2 Tambakbayan, Yogyakarta, 55281 \\ Telp. (0274) 485363 Fak : (0274) 486256 email : jur_tiupn@ telkom.net
}

\begin{abstract}
ABSTRAK
Pengrajin di Desa Karassik, Kecamatan Kesu', Kabupaten Toraja Utara, Provinsi Sulawesi Selatan masih menggunakan alat tradisional dalam proses pembuatan Batik Sarita, hal ini memerlukan waktu yang cukup lama mulai dari pembuatan sketsa sampai proses penorehan cairan malam di atas kain dan diperlukan teknik membatik untuk menghasilkan produk batik yang berkualitas.Selain itu dalam proses pembuatan Batik Sarita diperlukan banyak peralatan.Tujuan dari penelitian ini adalah untuk merancang alat bantu untuk mempermudah proses pembuatan Batik Sarita.

Dalam penelitian ini perancangan alat bantu proses pembuatan Batik Sarita menggunakan metode perancangan produk model proses perancangan deskriptif French. Perancangan dengan menggunakan metode ini diawali dengan menentukan kebutuhan konsumen untuk menganalisis masalah. Setelah itu dilakuak perancangan konsep dan mencari solusi alternatif untuk memenuhi kebutuhan konsumen. Setelah didapatkan solusi alternatif, langkah selanjutanya adalah membuat prototype,,dan langkah terakhir adalah melakukan uji coba terhadap alat bantu proses pembuatan Batik Sarita yang sesuai dengan konsep rancangan.

Penelitian ini telah berhasil mengembangkan alat bantu proses pembuatan Batik Sarita, dikembangkan dengan memodifikasi Pantograph dan merancang kompor elektrik dalam proses pembuatan Batik Sarita. Hasil yang diperoleh dari alat rancangan baru mampu mempermudah proses pembuatan Batik Sarita dimana pengrajin tidak perlu membuat sketsa atau pola di atas kain. Sketsa dapat dibuat di atas kertas yang bisa digunakan berkali-kali. Selain itu suhu dan keenceran cairan malam dapat dikontrol dengan mudah karena menggunakan kompor elektrik yang dilengkapi dengan sensor suhu. Dalam proses penorehan malam di atas kain dapat dilakukan dengan mudah, cukup menggerakkan Pantograph mengikuti pola yang sudah ada.
\end{abstract}

Kata kunci :Perancangan Alat, Batik Sarita, Alat Bantu

\section{PENDAHULUAN}

Batik Sarita merupakan batik tulis asli Toraja yang terbuat dari kain katun yang memiliki motif khas budaya Toraja dengan menggunakan bambu sebagai alat untuk menorehkan cairan malam. Batik Sarita tercipta dari pengembangan budaya yang pada awalnya hanya dalam bentuk ukiran yang terpahat di rumah adat. Warna khas Batik Sarita yaitu hitam, putih, merah, dan kuning. Dalam proses pembuatan Batik Sarita pengrajin memerlukan waktu yang lama mulai dari pembuatan sketsa sampai proses penorehan cairan malam di atas kain. Lama proses pengerjaan batik kurang lebih 1-5 minggu tergantung dari tingkat kerumitan motif dan jumlah warna yang digunakan. Selain itu minat masyarakat untuk membuat batik masih sangat rendah disebabkan karena proses pembuatan batik yang cukup lama dan juga membutuhkan keahlian membatik untuk menghasilkan produk batik yang berkualitas. Padahal permintaan terhadap Batik Sarita semakin meningkat. Oleh karena itu, penelitian ini dilakukan untuk merancang sebuah alat bantu untuk mempermudah proses pembuatan Batik Sarita. Dengan adanya alat ini diharapkan dapat membantu pengrajin untuk membuat Batik Sarita lebih cepat dan meningkatkan minat masyarakat untuk ikut membuat batik.

\section{LANDASAN TEORI}

Perancangan dan Pengembangan Produk

Dalam merancang sebuah produk, terdapat beberapa tahapan yang harus dilakukan untuk mempermudah pelaksanaan 
pembuatan. Tahap tersebut adalah sebagai berikut (Ulrich dan Eppinger, 2001):

a) Desain

Desain merupakan langkah awal dalam perancangan pembuatan produk yang memiliki output berupa sketsa gambar suatu produk yang akan diproduksi.

b) Manufaktur

Manufaktur merupakan bagian dalam proses produksi, terutama untuk menentukan langkah-langkah yang diperlukan untuk pembuatan produk.

c) Perencanaan bahan Produksi

Merupakan perencanaan yang berhubungan dengan bahan-bahan produksi yang akan digunakan untuk pembuatan produk, mencakup bahan utama dan bahan pendukung.

d) Perencanaan biaya produksi

Merencanakan berapa besar biaya yang akan dikeluarkan dalam pembuatan suatu produk.

Pengembangan produk adalah serangkaian aktivitas yang diawali dari menganalisis persepsi peluang pasar dan diakhiri dengan tahapan produksi, penjualan, dan pengiriman barang. Dalam mengembangkan produk, ada tiga konsep yang bisa dilakukan, yaitu (Ulrich dan Eppinger, 2001):

a. Proses pengembangan generik

Dalam mengembangkan suatu produk, diperlukan langkah-langkah yang strategis dan terstruktur agar produk yang akan dikembangkan bisa dianalisis san dapat diketahui kekurangan yang ada, sehingga produk baru yang akan dikembangkan akan lebih sempurna. Secara umum pengembangan produk ada 6 (enam) tahap proses, yaitu perencanaan, pengembangan konsep, perancangan tingkat sistem, perancangan detail, pengujian dan perbaikan, dan memulai produksi awal.

b. Proses pengembangan konsep dari proses awal hingga akhir

Proses awal hingga akhir dalam sebuah konsep pengembangan produk adalah suatu proses yang terdiri dari beberapa kegiatan yang saling berhubungan, saling tersusun, dan saling berinteraksi. Proses awal hingga akhir ditunjukkan pada gambar berikut ini:

c. Proses pengembangan model perspektif

Model perspektif adalah model konvensional yang menggambarkan kelebihan atau kekurangan, proses desain secara heuristik, dan beberapa cara membuat model perspektif dari proses desain. Model perspektif mendorong perancang untuk mengaplikasikan cara-cara peningkatan kinerja dalam beberapa waktu kemudian. Perancang menawarkan model perspektif yang lebih algoritmik dengan menggunakan prosedur secara sistematis dan menyediakan metodologi desain tertentu. Sebagian besar model perspektif menekankan kebutuhan lebih kritis untuk mendapatkan konsep solusi. Konsep solusi yang dimaksud adalah mencoba untuk memastikan bahwa masalah desain dipahami secara keseluruhan, tidak ada unsur-unsur penting dari permasalahan tersebut untuk diidentifikasi (Cross, 1994).

Model Proses Perancangan Deskriptif French, Model proses perancangan sering digambarkan dalam bentuk aliran-diagram, perkembangan perancangan menunjukkan bahwa proses selalu melanjutkan dari satu tahap ke tahap berikutnya.Tetapi dengan cara umpan balik dan berulang kembali ketahap sebelumnya juga sering diperlukan. Franch telah mengembangkan model lebih rinci dari proses perancangan berdasarkan analisis masalah, konseptual perancangan, perwujudan dari skema dan rincian. Proses ini dimulai dengan peryataan awal dari sebuah kebutuhan, dan kegiatan perancangan pertama adalah analisis masalah. French menunjukkan bahwa analisis masalah merupakan bagian kecil tetapi penting dari proses keseluruhan. Proses perancangan dengan Model French dapat dilihat pada Gambar 1. 


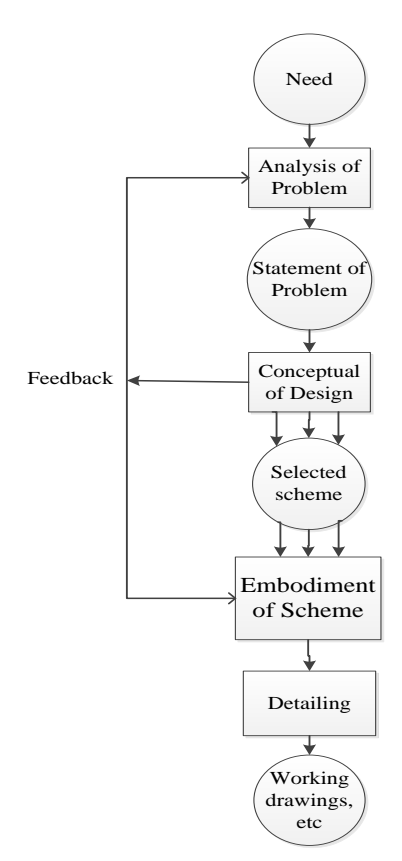

Gambar 1. Model French

\section{METODOLOGI PENELITIAN}

Data yang digunakan pada penelitian ini adalah data tentang proses pembuatan Batik Sarita yang biasa dilakukan pengrajin. Data diperoleh dengan menyebarkan kuesioner, melakukan wawancara dengan pengrajin, dan melakukan observasi lapangan. Kuesioner yang disebarkan berjumlah 30 dan responden yang dijadikan subjek penelitian adalah pengrajin di Desa Karassik, Kecamatan Kesu', Kabupaten Toraja Utara, Provinsi Sulawesi Selatan. Jika data telah berhasil diperoleh, maka langkah selanjutnya adalah melakukan perancangan terhadap alat bantu proses pembuatan Batik Sarita dengan Metode French.

Langkah yang dilakukan dalam melakukan pengolahan data yaitu dengan mengumpulkan data tentang proses pembuatan Batik Sarita, keluhan, kendala, dan keinginan pengrajin terhadapap alat bantu yang akan dirancang. Kuesioner disebarkan langsung kepada pembatik dengan skala penilaian yang digunakan adalah skala Likert.

a. Uji validitas

Uji validitas dimaksudkan untuk mengetahui apakah tes yang dilakukan dengan menggunakan kuesioner mempunyai tingkat validitas yang tinggi. Uji validitas dilakukan dengan mengukur korelasi antara variabel atau item dengan skor total variabel. Uji validitas yang dilakukan dalam penelitian ini yaitu dengan membuat pertanyaan-pertanyaan dalam kuesioner tentang kondisi proses pembuatan batik, hasil uji validitas inilah yang akan membuktikan benar atau tidaknya pengrajin membutuhkan alat bantu proses pembuatan Batik Sarita.

b. Uji Reliabilitas

Reliabilitas adalah tingkat kepercayaan hasil suatu pengukuran. Reliabilitas merupakan suatu ciri atau karakter utama instrumen pengukuran yang baik. Reliabilitas disebut juga konsistensi, kestabilan, keterpercayaan, kehandalan dan sebagainya. Alat yang memenuhi syarat reliabilitas adalah alat yang memberikan hasil yang sama apabila digunakan oleh orang yang berbeda dan waktu yang berbeda pula. Pengujian reliabilitas dalam penelitian ini yaitu pengujian tentang pertanyaan-pertanyaan yang terdapat dalam kuesioner yang berkaitan dengan proses pembuatan Batik Sarita, dari hasil inilah akan diketahui bahwa butir pertanyaan yang diajukan dapat dipercaya, dapat diterima dan dapat dipertanggungjawabkan secara ilmiah.

Perancangan produk, Tahap Penentuan Kebutuhan, Langkah yang dilakukan pada tahap ini adalah melakukan survey pendahuluan yang meliputi observasi lapangan, wawancara, dan penyebaran kuesioner. Langkah ini dilakukan untuk mencari informasi tentang permasalahan dan kendala yang dihadapi pembatik. Setelah data diperoleh, langkah selanjutnya adalah melakukan pengolahan data hasil kuesioner dan wawancara. Dari hasil pengolahan data kuesioner diperoleh atribut-atribut dalam Tabel 1. 
Tabel 1. Atribut keinginan terhadap alat

\begin{tabular}{|c|l|}
\hline No & Atribut \\
\hline 1. & Alar mudah dioperasikan \\
\hline 2. & Alat nyaman digunakan \\
\hline 3. & $\begin{array}{l}\text { Memiliki dimensi ukuran yang } \\
\text { sedang }\end{array}$ \\
\hline 4. & Mudah dalam melakukan perawatan \\
\hline 5. & Alat murah dan tahan lama \\
\hline 6. & Material yang digunakan tahan karat \\
\hline 7. & Memiliki kompor elektrik \\
\hline 8. & $\begin{array}{l}\text { Alat multifungsi, tiga tahap bisa } \\
\text { langsung dilakukan (pembuatan } \\
\text { sketsa, melelehkan malam, } \\
\text { menorehkan cairan malam) }\end{array}$ \\
\hline 9. & $\begin{array}{l}\text { Sketsa atau pola bisa digunakan } \\
\text { berkali-kali }\end{array}$ \\
\hline 10. & Mempersingkat proses membatik \\
\hline 11. & Mampu meningkatkan kualitas \\
\hline
\end{tabular}

Langkah selanjutnya adalah melakukan uji Validitas dan uji Reliabilitas dan menghitung nilai alpha acrobach pada software Statistical Product and Service Solution (SPSS).

Tabel 2. Hasil uji validitas

\begin{tabular}{|c|c|c|c|}
\hline \multicolumn{4}{|c|}{$\boldsymbol{r}$ tabel 0,361 } \\
\hline No. Butir & $\boldsymbol{r}$ hitung & Hasil & Ket. \\
\hline 1. & 0,552 & $>0,361$ & Valid \\
\hline 2. & 0,377 & $>0,361$ & Valid \\
\hline 3. & 0,632 & $>0,361$ & Valid \\
\hline 4. & 0,476 & $>0,361$ & Valid \\
\hline 5. & 0,410 & $>0,361$ & Valid \\
\hline 6. & 0,403 & $>0,361$ & Valid \\
\hline 7. & 0,414 & $>0,361$ & Valid \\
\hline 8. & 0,554 & $>0,361$ & Valid \\
\hline 9. & 0,588 & $>0,361$ & Valid \\
\hline 10. & 0,671 & $>0,361$ & Valid \\
\hline 11. & 0,445 & $>0,361$ & Valid \\
\hline
\end{tabular}

Dari Tabel 2. diketahui bahwa nilai $r$ untuk tiap-tiap butir pertanyaan (realita) mempunyai nilai lebih besar daripada nilai $r$ pada tabel (ekspektasi), sehingga atributatribut yang dinyatakan dalam kuesioner pada penelitian ini dinyatakan valid.

Tabel 3. Hasil uji reliabilitas

\begin{tabular}{|c|c|c|}
\hline Atribut & $\boldsymbol{\alpha}$ tetapan = 0,6 & Ket \\
\hline $\begin{array}{c}\text { Cronbach's } \\
\text { Alpha }\end{array}$ & 0,823 & Reliable \\
\hline
\end{tabular}

Berdasarkan hasil uji reliabilitas pada Tabel 3. dapat disimpulkan bahwa atribut-atribut pada kuesioner dinyatakan reliabel.

Tahap Pengembangan Konsep, Tahap ini diawali dangan mengidentifikasi kekurangan dari alat-alat yang ada saat ini lalu membangkitkan alternatif perbaikan dengan membuat Morphological chart.

\begin{tabular}{|c|c|c|c|c|}
\hline \multirow{2}{*}{ No. } & \multirow{2}{*}{ Fungsi } & \multicolumn{3}{|c|}{ Cara Mencapai Fungsi } \\
\hline & & 1 & 2 & 3 \\
\hline 1 & Bentuk rangka & & & \\
\hline 2 & Bahan Rangka & Baja $<$ & Besi & Alimunium \\
\hline 3 & Ukuran Rangka & $\begin{array}{l}130 \mathrm{~cm} \times 140 \\
\mathrm{~cm} \times 75 \mathrm{~cm}\end{array}$ & $\begin{array}{r}100 \mathrm{~cm} \times 100 \\
\mathrm{~cm} \times 75 \mathrm{em}\end{array}$ & $\begin{array}{l}100 \mathrm{~cm} \times 140 \\
\mathrm{~cm} \times 32 \mathrm{~cm}\end{array}$ \\
\hline 4 & Bahan kompor \& canting & Almunium & Kuningan & Tembaga \\
\hline 5 & Bentuk kompor \& canting & Tabunio & Perseo & \\
\hline 6 & Jenis Pemanas (Heater) & Basah $<$ & - & Eerring \\
\hline 7 & Warna & Hitam $<$ & Coklat & sither \\
\hline 8 & Usia pakai & $<4$ tahun & 4-8 aliun & $>8$ tahun \\
\hline 9 & Fungsiutama & & Gombltik & \\
\hline 10 & Fungsitambahan & $\cdot$ & $\begin{array}{l}\text { Meja kerja } \\
\text { Batik cap }\end{array}$ & \\
\hline 11 & Bahan tambahan & Kayu $<$ & Karet & Plastik \\
\hline 12 & Harga & Rp.1.500.000,- & Rp.3.000.000,-- & Rp $\$ .500 .000$;- \\
\hline
\end{tabular}

Gambar 2. Morphological chart

Tahap Perancangan Wujud, Langkah kerja yang dilakukan dalam tahap ini adalah dengan membuat gambar rancangan menjadi wujud gambar 3 dimensi setelah gambar rancangan selesai dibuat pada tahap sebelumnya. Gambar kerja yang dibuat diurutkan berdasarkan komponen-komponen yang digunakan untuk merakit alat bantu pembuatan Batik Sarita secara utuh. 


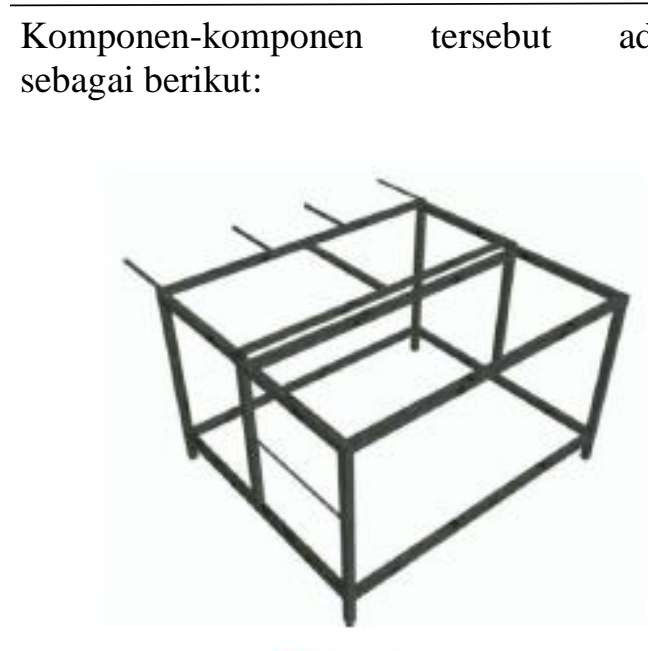

Gambar 3. Rangka meja kerja

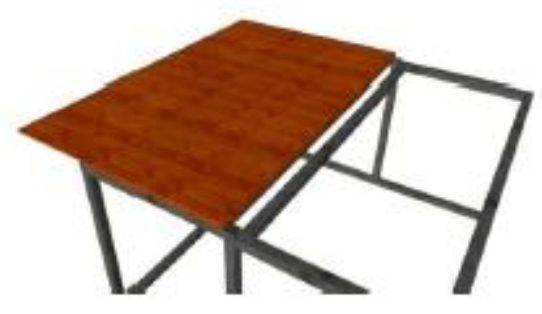

Gambar 4. Papan alas kerja

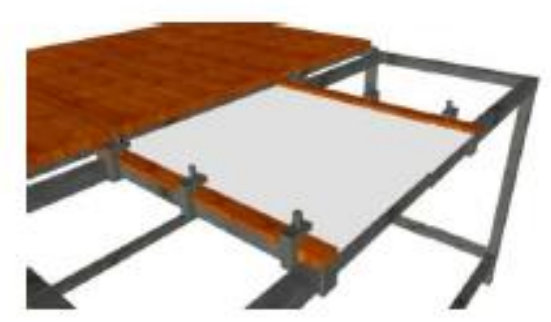

Gambar 5. Penjepit kain

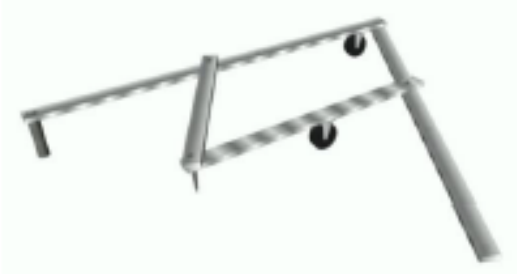

Gambar 6. Pantograph adalah

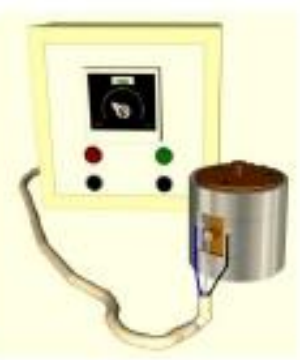

Gambar 7. Kompor eleltrik

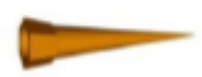

Gambar 8. Canting

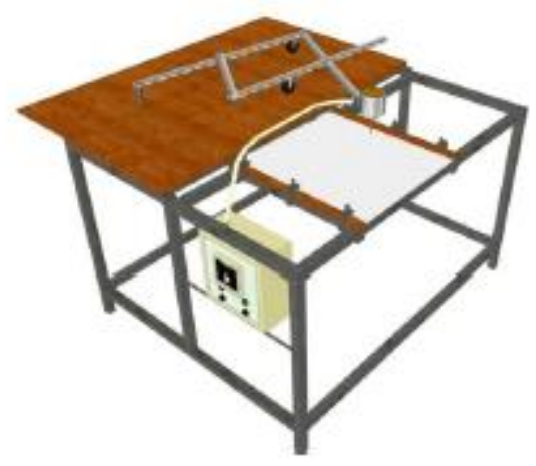

Gambar 9. Rancangan keseluruhan

Tahap Perancangan Rinci (Detail Design), Langkah awal yang dilakukan pada tahap ini adalah menyusun bill of material (BOM) perakitan komponen-komponen alat bantu proses pembuatan Batik Sarita. BOM alat bantu baru dapat dilihat pada Gambar 10 . Dikarenakan begitu banyaknya komponen yang digunakan, maka pembuatan BOM dibatasi hanya sampai pada level 3 saja. 



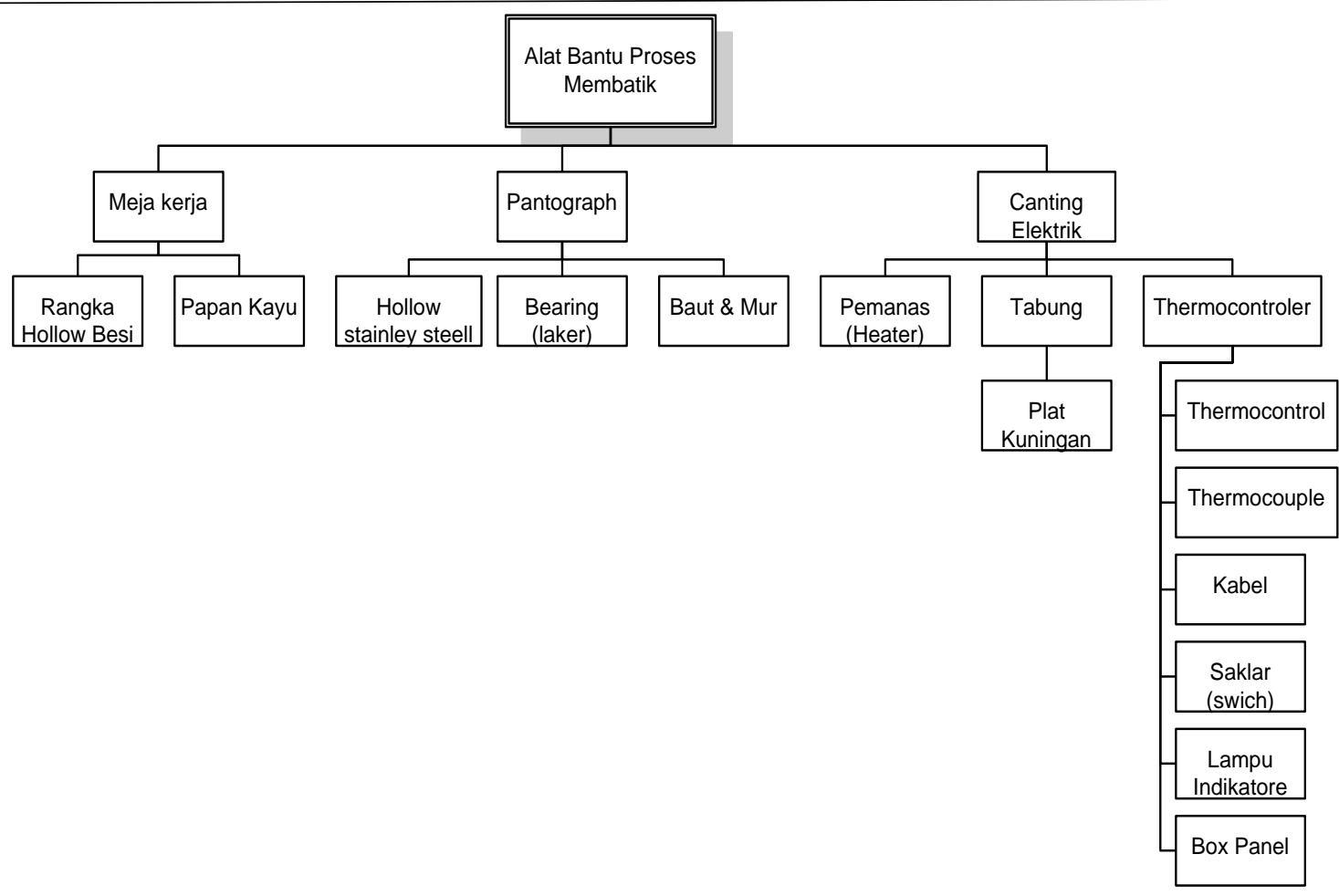

Gambar 10. Bill of material alat bantu proses pembuatan Batik Sarita

Berdasarkan BOM yang telah disusun, dibuatlah alat bantu proses pembuatan Batik Sarita hasil pengembangan, seperti terlihat pada Gambar 11.

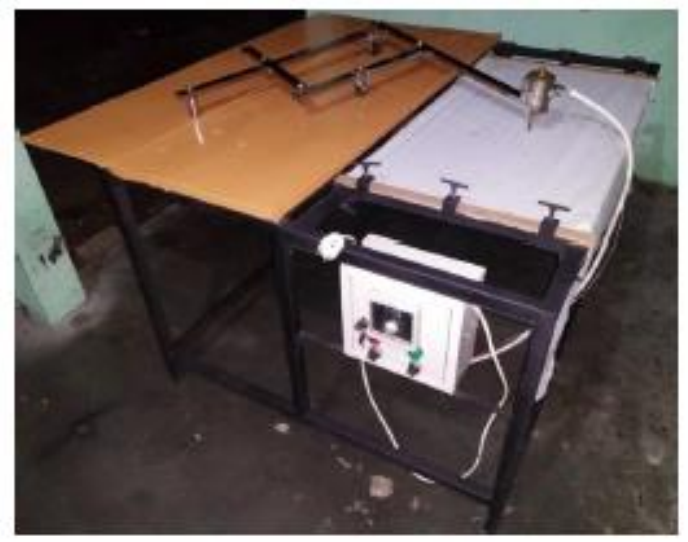

Gambar 11. Alat bantu proses pembuatan Batik Sarita hasil pengembangan

\section{ANALISIS HASIL}

Analisis produktivitas sangat penting dilakukan karena untuk mengetahui sejauh mana pengembangan dan penelitian ini berhasil dilakukan. Analisis yang dilakukan adalah penggunaan tenaga kerja sebagai salah satu komponen input pada proses pembuatan Batik Sarita itu sendiri, dan output yang mampu dihasilkan dari alat bantu hasil pengembangan.

1. Input

Input dari sebuah proses produksi diantaranya adalah tenaga kerja dan alat, dalam hal ini proses yang dilakukan adalah proses pembutan Batik Sarita. Sebelum dilakukan pengembangan, proses pembuatan Batik Sarita biasanya dilakukan pengrajin dengan pembuatan sketsa di atas kain, selanjutnya menyiapkan cairan malam dengan terus memperhatikan suhu dan tingkat keenceran cairan malam. Setelah dilakukan pengembangan, pengrajin cukup fokus dengan pergerakan alat yang mengikuti pola karena pola sudah dibuat sebelumnya di atas kertas yang bisa digunakkan berkali-kali, suhu dan keenceran cairan malam sudah dapat dikontrol dengan menggunakan thermocontrol yang terdapat di kompor elektrik. Hal ini menunjukkan adanya penghematan kerja ketika proses pembuatan 
Batik Sarita dilakukan menggunakan alat bantu hasil pengembangan.

\section{Proses}

Perbandingan proses membatik secara tradisional dengan membatik dengan menggunakan alat bantu hasil pengembangan dapat dilihat pada Gambar 12.
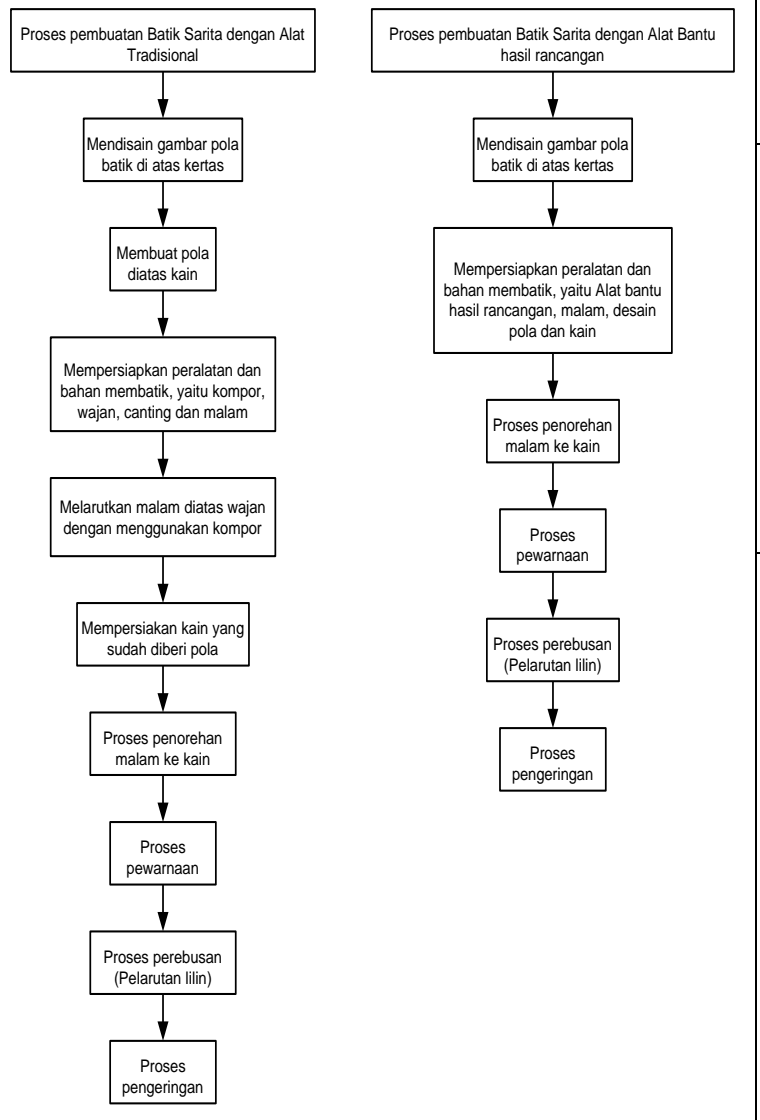

Gambar 12. Perbandingan proses pembatikan

\section{Output}

Dalam proses pembuatan Batik Sarita secara tradisional banyak peralatan yang digunakan seperti: canting, kompor, wajan, pensil untuk membuat pola di atas kain. Dalam proses ini semua peralatan dalam posisi terpisah dengan fungsi dan penanganan yang berbeda-beda. Dengan menggunakan alat bantu hasil pengembangan, semua fungsi peralatan dijadikan satu dan ditangani sekaligus dalam satu proses. Dalam proses tersebut tidak dilakukan pembuatan pola batik di atas kain. Analisis dilakukan hanya pada tahap pembuatan pola sampai penorehan malam. Hasil analisis penggunaan alat tradisional dengan alat bantu hasil pengembangan dapat dilihat pada Tabel 4 .

Tabel 4. Perincian perbedaan proses

\begin{tabular}{|c|c|c|}
\hline Kegiatan & Alat tradisional & $\begin{array}{l}\text { Alat bantu hasil } \\
\text { pengembangan }\end{array}$ \\
\hline Membatik & $\begin{array}{l}\text { Memerlukan } \\
\text { peralatan terpisah } \\
\text { berupa pensil, } \\
\text { kompor, wajan, } \\
\text { canting. }\end{array}$ & $\begin{array}{l}\text { Hanya } \\
\text { memerlukan satu } \\
\text { (1) alat }\end{array}$ \\
\hline $\begin{array}{l}\text { Pembuatan } \\
\text { Pola }\end{array}$ & $\begin{array}{l}\text { Membuat disain } \\
\text { motif batik di atas } \\
\text { kertas } \\
\text { Membuat pola di } \\
\text { atas kain } \\
\text { menggunakan } \\
\text { pensil sesuai } \\
\text { dengan desain } \\
\text { motif batik }\end{array}$ & $\begin{array}{l}\text { Membuat disain } \\
\text { motif batik di atas } \\
\text { kertas } \\
\text { Tidak perlu } \\
\text { membuat pola di } \\
\text { atas kain cukup } \\
\text { mengikuti desain } \\
\text { motif batik. }\end{array}$ \\
\hline $\begin{array}{l}\text { Penyediaan } \\
\text { bahan } \\
\text { (malam) }\end{array}$ & $\begin{array}{l}\text { Menyediakan } \\
\text { kompor dan wajan } \\
\text { Suhu tidak stabil, } \\
\text { keenceran malam } \\
\text { harus selalu } \\
\text { diperhatikan, jika } \\
\text { terlalu encer } \\
\text { panas kompor } \\
\text { harus diturunkan } \\
\text { dan sebaliknya } \\
\text { jika kurang encer } \\
\text { panas kompor } \\
\text { harus dinaikkan. }\end{array}$ & $\begin{array}{l}\text { Suhu stabil karena } \\
\text { mengunakan } \\
\text { kompor elektrik } \\
\text { yang dilengkapi } \\
\text { dengan sensor } \\
\text { panas } \\
\text { (thermocouple) } \\
\text { dan pengatur suhu } \\
\text { (thermocontrol) }\end{array}$ \\
\hline $\begin{array}{l}\text { Penorehan } \\
\text { malam }\end{array}$ & $\begin{array}{l}\text { Proses penorehan } \\
\text { malam pada kain } \\
\text { memerlukan } 3 \\
\text { langkah yaitu, } \\
\text { mengambil, } \\
\text { meniup, dan } \\
\text { menorehkan. }\end{array}$ & $\begin{array}{l}\text { Proses penorehan } \\
\text { pada kain hanya } \\
\text { memerlukan satu } \\
\text { (1) langkah karena } \\
\text { canting dirancang } \\
\text { langsung } \\
\text { terhubung ke } \\
\text { kompor elektrik. }\end{array}$ \\
\hline
\end{tabular}

\section{KESIMPULAN}

Penelitian ini berhasil mengembangkan alat bantu proses untuk pembuatan Batik Sarita. Proses pembuatan batik yang awalnya dikerjakan menggunakan alat-alat tradisonal, dikembangkan dengan 
memodifikasi pantograph dan merancang kompor elektrik. Hasil yang diperoleh dari alat rancangan baru mampu mempermudah proses pembuatan Batik Sarita dimana pengrajin tidak perlu membuat sketsa atau pola di atas kain. Sketsa dapat dibuat di atas kertas yang bisa digunakan berkali-kali. Selain itu suhu dan keenceran cairan malam dapat dikontrol dengan mudah karena menggunakan kompor elektrik yang dilengkapi dengan sensor suhu. Dalam proses penorehan malam di atas kain dapat dilakukan dengan mudah, cukup menggerakkan pantograph mengikuti pola yang sudah ada.

Berdasarkan hasil penelitian, ada beberapa hal yang bisa menjadi bahan pertimbangan untuk penelitian selanjutnya, pertimbangan tersebut meliputi hal-hal sebagai berikut:

1. Pengembangan alat sebaiknya memperhatikan prinsip-prinsip kerja ergonomi.

2. Lebih memperhatikan hal-hal yang bersifat sangat teknis karena akan sangat berpengaruh terhadap hasil dan tujuan awal perancangan.

3. Pada pantograph seharusnya dilakukan perhitungan beban agar gerakan pantograph lebih mudah.

4. Mempertimbangkan dimensi alat agar tidak terlalu besar
5. Penelitian selanjutnya diharapkan dapat mempertimbangkan dan menambahkan atribut-atribut lain yang belum tertulis dalam penelitian ini.

\section{DAFTAR PUSTAKA}

Cross, N., 1994 Engineering Design Methods: Strategies for Product Design, Second Edition, John Wiley and Sons Ltd

Daniel, 2013, Kemenparekraf Dukung Wujudkan Revitalisasi Batik Toraja. http://www.antarasulsel.com, diakses Januari 2015

Ginting, R., 2010, Perancangan Produk, Graha Ilmu, cetakan pertama, Yogyakarta.

Kusrianto. A., 2013, Batik, Filosofi, Motif, \& Kegunaan, Andi, Yogyakarta

Kwan W., 2014, Revitalisasi Batik Toraja ; Ne' One. http://redayabatik.com diakses Januari 2015

Kwan W., 2014, Proses pembuatan Batik Sarita. http://redayabatik.com diakses Januari 2015

Magribi M. , 2013. Pantograph .http:// geoact.blogspot.com ,diakses Maret 2015

Ulrich dan Eppinger, 2001, Perancangan dan Pengembangan Produk, Edisi Pertama, Salemba Teknika, Jakarta 